\title{
REAL ESTATE INVESTMENT DECISIONS I: COMMERCIAL OFFICE PROPERTY ACQUISITIONS
}

\author{
Jonathan Breazeale
}

Sam Houston State University • Huntsville, TX

\section{CASE DESCRIPTION}

The primary subject matter of this case concerns the financial analysis of the acquisition of a commercial office property. Secondary issues examined include aspects of office REITs - with which most business students are unfamiliar. The case has a difficulty level of four, appropriate for undergraduate seniors. The case is designed to be taught in a single 80 minute class period and is expected to require three to four hours of outside preparation by students (depending on their level of spreadsheet familiarity).

\section{CASE SYNOPSIS}

You are a member of the investment committee and serve as an outside director on the board of City View Office, a publicly traded Real Estate Investment Trust (REIT) with a focus on commercial office properties. It is the fourth quarter of 2005, and management's acquisition team has just submitted a package for your approval that will solidify the offer that has just been presented on The Forum, a beautiful six-story Class A property in the Energy Corridor of Houston, Texas. Your vote will determine whether or not the firm moves forward with the purchase.

\section{REAL ESTATE INVESTMENT TRUSTS (REITS)}

Real Estate Investment Trusts (REITs) were created by Congress in 1960 to allow small investors access to capital intensive, large-scale real estate. Small investors are allowed to pool their equity in REITs just as they would in any other corporation, enabling them to participate in an industry that was formerly inaccessible for the purpose of diversifying their personal portfolios. REITs own and, in many cases, operate income-producing real estate of a specific type or types. For instance, there are REITs that own office buildings, industrial properties, apartments, hotels, shopping centers, timber, or a combination of these and other types of real estate. REITs may also own financial assets such as mortgages and other real estate financing. The most important aspect of a REIT is that it does not pay corporate income taxes as long as it meets certain requirements - the most important of which 
is that it distributes $90 \%$ of its otherwise taxable income to its shareholders each year in the form of dividends. It is a great advantage for equity investors to receive untaxed distributions, but the REIT is faced with the difficulty of having to access capital markets frequently for external funding since it cannot use much of its net income to fund investment in new assets. In other words, REITs have very small amounts of retained earnings on their balance sheets.

Due to the large amount of depreciation arising from investment in long-term fixed assets and the large gains/losses that can result from the sale of large assets, REITs utilize measures of financial performance that deviate somewhat from GAAP measures reported by other public corporations. The National Association of Real Estate Investment Trusts ${ }^{\circledR}$ (NAREIT - www.nareit.com) is an industry organization that provides services to REITs and acts on behalf of its member firms in lobbying and other political efforts. NAREIT defines the measure Funds from Operations (FFO) as net income (on a GAAP basis) excluding gains or losses from sales of most property as well as depreciation of real estate (National Association of Real Estate Investment Trusts, Inc., 2007). This provides a measure of operating performance more consistent with the recurring nature of the REIT's operations rather than net income that is influenced by large one-time transactions such as asset sales or large changes in depreciation brought about by either sales or acquisitions. Therefore, FFO provides a measure that is more consistent with the types of assets held by REITs and allows for better comparison of the operating performance of multiple REITs as well as trend analysis of individual REITs year after year.

While FFO provides a more consistent measure of operating performance for the real estate industry, it is not well suited to provide a measure of how much cash is available for a REIT to pay its all-important dividends. As a result, some REITs also disclose Funds Available for Distribution (FAD) which might also be reported as Cash Available for Distribution (CAD) or Adjusted FFO. While FFO is "standardized" across the industry, the calculation of FAD is not. However, FAD is essentially FFO less capital expenditures (tenant improvement allowances, leasing commissions, non-revenue enhancements, capital improvements to new acquisitions, etc.) that reduce the actual amount of cash that is available to distribute to shareholders.

At the start of 2005, there were more than 200 publicly traded REITs on U.S. stock exchanges with assets valued at nearly $\$ 1$ trillion. Office properties comprise approximately $19 \%$ of the total value of assets owned by REITs - making them the largest property type in which REITs are invested (National Association of Real Estate Investment Trusts, 2007). 


\section{CITY VIEW OFFICE PROPERTIES}

City View Office has been taking it on the chin recently. Falling occupancy and rental rates nationwide, along with rising insurance and electricity costs, have resulted in an inability to cover the dividend for the past three years. Hot money has also entered every major real estate market in the country - making the acquisition of assets more difficult with the high cost of corporate capital. Fortunately, City View Office has just closed on a joint venture with a large public employee pension fund that will allow them to pursue investment opportunities with acceptable lower yields. Additional yield for City View will come from management, leasing, and construction management fees associated with their wholly-owned realty service subsidiary. Terms of the joint venture state that City View Realty Services has a 10 -year non-cancelable contract for these services on every acquisition made by the joint venture. Table 1 summarizes the joint venture's current purchasing criteria.

Table 1

City View Office Properties' Published Joint Venture Acquisition Criteria

\begin{tabular}{|c|c|}
\hline Size: & $\begin{array}{l}100,000 \text { to } 1,500,000 \text { square feet, multi-story }(250,000 \text { for new } \\
\text { markets) }\end{array}$ \\
\hline Quality: & Class $\mathrm{A}, \mathrm{A}-$ or $\mathrm{B}+$ \\
\hline Leasing: & $70 \%$ to $100 \%$ Leased to Quality Credit Tenants \\
\hline Yield: & $\begin{array}{l}\text { 7.0\% Capitalization Rate based on } 92 \% \text { occupancy, risk and quality } \\
\text { of tenants. Unleveraged IRR of } 8.0 \% \text {. }\end{array}$ \\
\hline Ownership: & $100 \%$ fee simple \\
\hline Parking: & $\begin{array}{l}\text { Parking must adequately accommodate market and building code } \\
\text { requirements as well as service the building at } 100 \% \text { occupancy. }\end{array}$ \\
\hline $\begin{array}{l}\text { Replacement } \\
\text { Cost: }\end{array}$ & $\begin{array}{l}\text { Current replacement cost cannot exceed the purchase price. } \\
\text { Replacement cost is the total development cost to recreate the } \\
\text { property - and its economics - in today's dollars. }\end{array}$ \\
\hline Markets: & $\begin{array}{l}\text { New York } \\
\text { Boston } \\
\text { Washington D.C. } \\
\text { Atlanta }\end{array}$ \\
\hline Tenants: & $\begin{array}{l}\text { Preference for buildings with a major tenant ( } 30 \% \text { or more of the total } \\
\text { rentable square feet) with at least } 5 \text { years remaining on lease. }\end{array}$ \\
\hline Debt: & Purchases are conducted in all cash. \\
\hline Disclaimer: & $\begin{array}{l}\text { At its sole discretion, City View has deviated and may deviate from its } \\
\text { published criteria. }\end{array}$ \\
\hline
\end{tabular}




\section{HOUSTON OFFICE MARKET}

Houston has been a bright spot in an otherwise dismal climate of economic expectations. Both occupancy and rental rates are on the rebound - as evidenced by the pace of construction in a majority of the submarkets. And, despite the recessionary overtones heard nationwide as a result of the retraction of inflated residential values, the heavy energy presence in Houston has somewhat insulated the commercial office market from the current economic downturn. Oil prices continue to climb, and that is good news for Houston. City would love to own more property in a market where expansion is actually occurring. Table 2 summarizes the current state of both the Houston Energy Corridor submarket and the overall Houston market.

Table 2

Class "A" Office Market Statistics

\begin{tabular}{|l|l|l|}
\hline Market Metric & Energy Corridor & Total Houston Market \\
\hline Size & $5,917,994$ Square Feet & $58,145,642$ Square Feet \\
\hline Vacancy & $5.7 \%$ & $15.5 \%$ \\
\hline Average Rental Rate & $\$ 22.68$ & $\$ 20.67$ \\
\hline
\end{tabular}

The Energy Corridor has long been known as the home of many top players in the energy industry. In close proximity to The Forum, British Petroleum, Exxon Mobil, Conoco Phillips, Shell Oil, Citgo, Halliburton, Schlumberger and Aker Maritime all lease substantial amounts of office space. Since oil and gas are the revenue generators for these firms, rental rates are very closely tied to oil and gas prices. When oil prices are high, these firms expand their operations and need additional office space. Historical rental rates for the Energy Corridor for the last 8 years have been $\$ 25.00, \$ 22.90, \$ 20.50, \$ 24.23, \$ 21.81, \$ 21.79, \$ 21.84$, and $\$ 22.68$, respectively.

\section{THE FORUM}

The Forum is a 150,000 square foot, six-story, Class A office building located within the Energy Corridor of Houston, Texas. It is $100 \%$ leased to four quality credit tenants, the largest of which (AAA Oil) occupies almost $75 \%$ of the building. The existing tenant base has a weighted average gross rental rate of $\$ 20.29$ and a remaining lease term of 44 months. Baring an unforeseen catastrophe, the initial yield of the investment appears solid. The property is located on a 5.3 acre site, 
and a 596 space parking garage services the building (approximately 4 spaces per 1000 square feet of rentable office space). The building and garage were completed in 1999, so no substantial capital expenditures are projected in the near future. The current quoted gross rental rate is $\$ 23.00$ per foot, and the seller is offering the property on a $100 \%$ fee simple basis.

The typical floor plate is approximately 25,000 square feet, and each floor is serviced by three Dover geared passenger elevators. An additional service elevator is located at a loading dock, and two hydraulic elevators service the four-level garage structure. Construction consists of a cast-in-place reinforced concrete slab at grade. The superstructure is comprised of reinforced cast-in-place concrete framing which includes columns, shear walls, elevated concrete floor slabs and roof slabs. Exterior walls are precast panels with fixed aluminum framed insulated glass windows. The roof is constructed of multi-ply bituminous built-up roofing membrane over the concrete deck and is toped with aggregate. Two 269-ton Trane rotary liquid chilled water units provide air conditioning to the building, and all systems are controlled by a Johnson Controls energy management system. The building uses pneumatic thermostats. The property is well lit on the exterior, and a superior life safety system is in place for fire and other contingencies. Management has provided you with the timeline submitted by the seller's broker in the Offering Memorandum. This information is contained in Table 3.

Table 3

Seller's Desired Transaction Timetable

\begin{tabular}{|c|c|}
\hline August 25, 2005 & $\begin{array}{l}\text { Announcement mailing delivered to prospective purchasers } \\
\text { Investor registration commences }\end{array}$ \\
\hline September 2, 2005 & $\begin{array}{l}\text { Distribution of Offering Memoranda to registered parties } \\
\text { Inspection tours conducted by appointment only } \\
\text { Informational meetings with property management and } \\
\text { interested parties } \\
\text { Additional material will be made available for review: } \\
\text { Form Purchase and Sale Agreement } \\
\text { Boundary Survey/Site Plan } \\
\text { Preliminary Title Report } \\
\text { Tenant Leases } \\
\text { Historical Operating Information } \\
\text { Property Tax Information } \\
\text { As-Built Floor Plans } \\
\text { Operating Budget }\end{array}$ \\
\hline
\end{tabular}




\begin{tabular}{|c|c|}
\hline October 5, 2005 & $\begin{array}{l}\text { Offers are due by letter of intent (LOI) in the broker's office by } \\
5 \text { P.M. } \\
\text { Investors are encouraged to include verifiable financial } \\
\text { information, transaction references and financial references } \\
\text { together with their LOls. }\end{array}$ \\
\hline October 12, 2005 & $\begin{array}{l}\text { Finalist(s) selected } \\
\text { Finalist interviews/conference calls } \\
\text { Reference checks } \\
\text { Investigation of funding capabilities }\end{array}$ \\
\hline October 14, 2005 & $\begin{array}{l}\text { Selection process completed } \\
\text { Notification to all remaining parties } \\
\text { Letter of Intent executed }\end{array}$ \\
\hline October 21, 2005 & $\begin{array}{l}\text { Purchase \& Sale Agreement executed } \\
\text { Formal due diligence period commences } \\
\text { Information delivery to purchaser }\end{array}$ \\
\hline November 18, 2005 & $\begin{array}{l}\text { Due diligence period ends } \\
\text { Earnest money deposit non-refundable }\end{array}$ \\
\hline December 2, 2005 & Closing \\
\hline
\end{tabular}

\section{FINANCIAL PROJECTIONS AND MARKET ASSUMPTIONS}

Management has included the Forum's Rent Roll and the broker's Pro Forma Cash Flow Statement that was included in the offering memorandum - along with the included assumptions. Tables 4, 5 and 6 detail these crucial sets of information. 


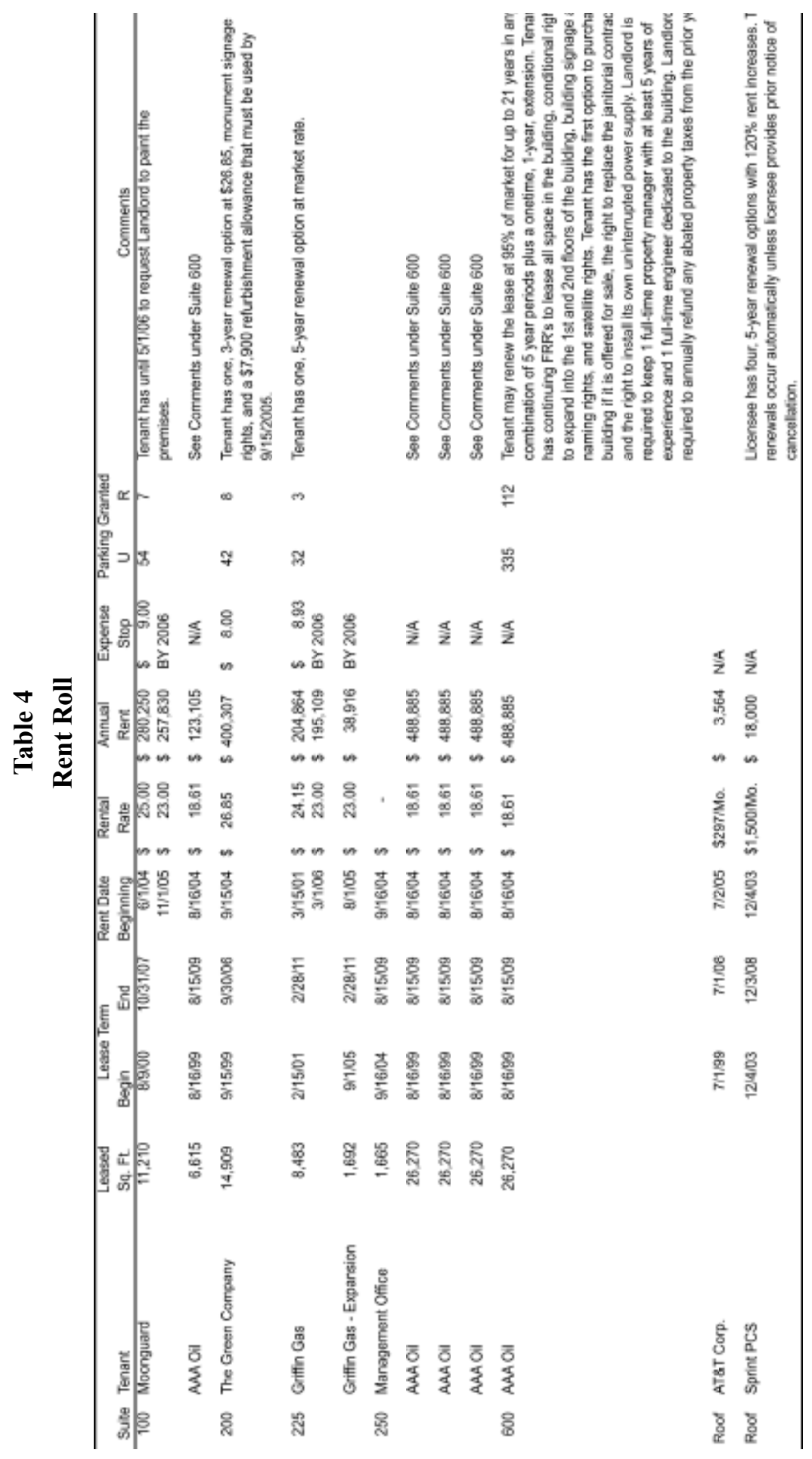




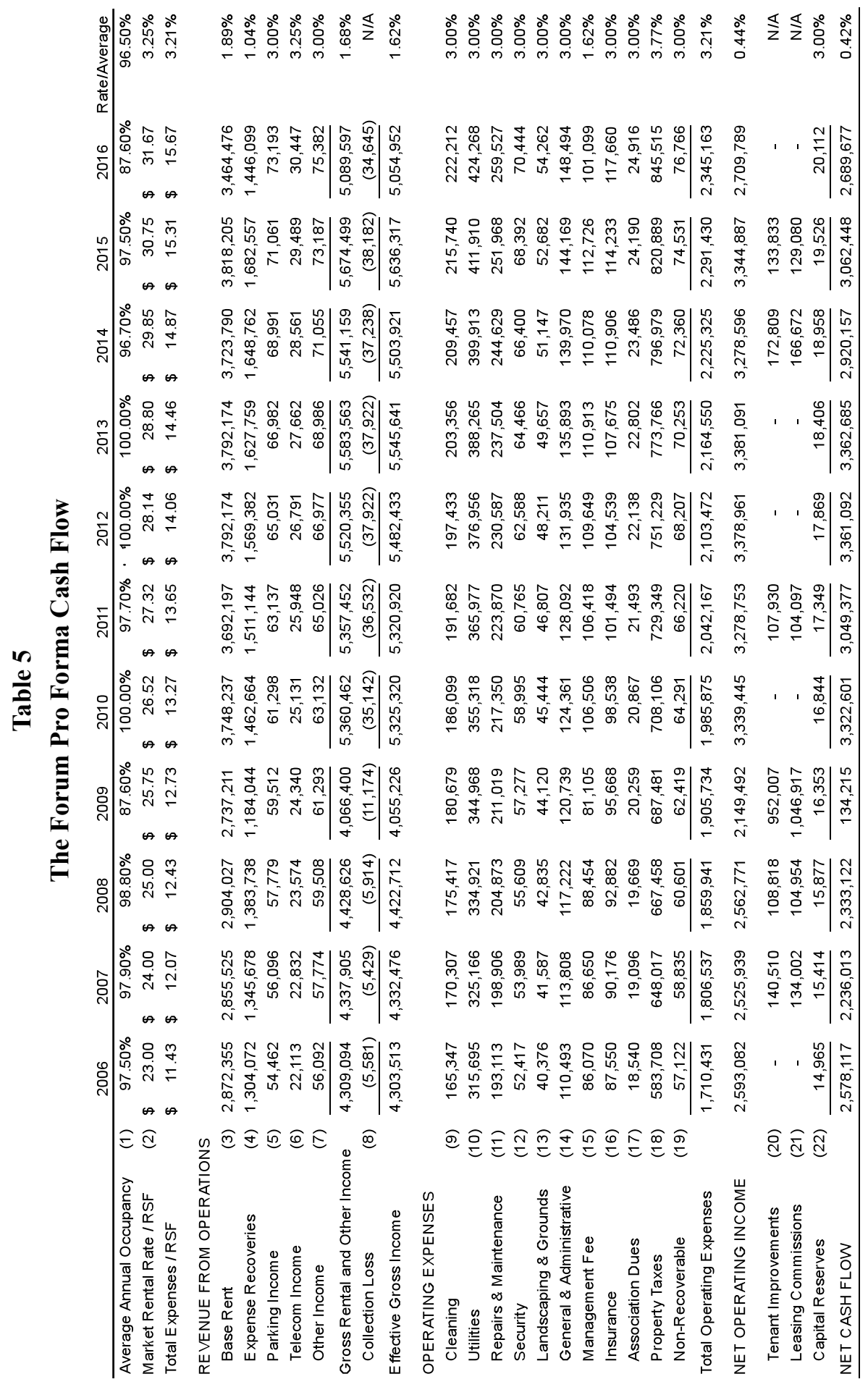




\section{Table 6}

\section{Notes to Pro Forma Cash Flow Statement}

(1) Average Annual Occupancy is subject to the broker's projected lease-up schedule and 12 months of downtime between non-recurring leases.

(2) Market Rental Rate / RSF is the assumed market base rent expressed as a gross rate with the tenant being responsible for its prorate share of recoverable operating expenses in excess of a base year amount. The Market Rental Rate for 2006, 2007, and 2008 is $\$ 23, \$ 24$, and $\$ 25$, respectively. Following 2008, the Market Rental Rate increases 3\% annually.

(3) Base Rent is projected pursuant to the terms of existing leases and the following assumptions:

- All expiring leases are subject to 12 months of downtime and seven-year renewal terms. AAA Oil is subject to an $80 \%$ renewal probability, while the other tenants are subject to a $65 \%$ renewal probability.

- Effective 09/01/2005, The Green Company (Suite 200) reduces its square footage from 16,694 sf to 14,909 sf and continues to pay a base rental rate of $\$ 26.85$.

- Effective 09/01/2005, Griffin Gas (Suite 225) expands by 1,692 sf to 10,175 sf and extends its current term from $02 / 28 / 2006$ to $02 / 28 / 2011$. The rate for the expansion space is $\$ 23.00$, while the rate for the original premises $(8,483 \mathrm{sf})$ remains at $\$ 24.15$ until $02 / 28 / 2006$. On $03 / 01 / 2006$, the rate for the original premises changes to $\$ 23.00$.

- Effective 09/01/2005, the management office, which provides no income for the duration of the analysis, expands by $93 \mathrm{sf}$ to $1,665 \mathrm{sf}$.

(4) Expense Recoveries reflects charges to tenants for their respective pro rata share of escalatable operating expenses. AAA Oil reimburses in proportionate share of operating expenses on a "NNN" basis plus a management fee equal to $3 \%$ of its base rental and recoveries (excluding the standard property management fee). All other tenants reimburse their proportionate share of recoverable operating expenses that exceed a stated or Base Year amount. Moonguard's $\$ 9.00$ expense stop resets to a 2006 Base Year effective 11/01/205, while The Green Company's $\$ 8.00$ expense stop remains constant throughout the analysis. Griffin Gas' original square footage $(8,483)$ is subject to an $\$ 8.93$ expense stop through $02 / 28 / 2006$, while the expansion space $(1,692)$ is subject to a 2006 Base Year effective 09/01/2005. Griffin's entire space is subject to a 2006 Base Year effective 03/01/2006. Per Griffin's lease, reimbursements 
are limited by the controlled growth of the property's recoverable operating expenses. Operating expenses cannot increase by more than $\$ 8,483$ annually through $08 / 31 / 2006$ and by $\$ 10,175$ annually thereafter. Base year stops are assumed for all renewals other than AAA Oil, which assumes a NNN recovery upon renewal.

(5) Parking Income is based on management's 2005 budgeted amount and inflates $3 \%$ annually.

(6) Telecom Income reflects the 2005 schedule rental income from Sprint $(\$ 18,000)$ and AT\&T $(\$ 3,417)$ agreements inflated $3.25 \%$ per annum.

(7) Miscellaneous Income consists of management's 2005 budgeted amounts for overtime utility charges $(\$ 50,100)$ and parking sales tax $(\$ 4,358)$ that inflate $3 \%$ annually.

(8) Collection Loss reflects a 1\% reduction to schedule base rent for non-credit tenants. The loss factor is not applied to AAA Oil or Griffin Gas during their initial terms.

(9) Cleaning includes charges for contract cleaning, window washing, trash removal, a day porter, cleaning supplies, and other cleaning expenses. Management's 2005 budgeted amount inflates 3\% annually.

(10) Utilities include the cost for electricity, water, and sewer. Management's 2005 budgeted amount of $\$ 356,600$ is reduced by $\$ 50,100$ to exclude directly billed overtime electricity, which is reclassified as a non-recoverable expense. The net amount of $\$ 306,500$ inflates 3\% annually.

(11) Repairs \& Maintenance represents all maintenance-related costs for the building including engineer salary and benefits, electrical, HVAC, plumbing, elevators, roof, painting, exterminating, supplies, life safety, interior landscaping, and other maintenance related items. Management's 2005 total budgeted amount inflates $3 \%$ per annum.

(12) Security consists of contract charges for guards' salaries and equipment monitoring. Management's 2005 budgeted amount inflates by 3\% per annum.

(13) Landscaping \& Grounds expense includes budgeted amounts for exterior landscaping and sweeping. The 2005 budgeted amount inflates by $3 \%$ per annum.

(14) General \& Administrative includes various business related costs associated with operating the building such as property manager salary and benefits, management office rent, corporate overhead, telephone, garage expenses, accounting fees, tax consulting fees, and other office related expenses. Management's 2005 budgeted amount inflates 3\% per annum. 
(15) Management Fee is calculated as $2 \%$ of effective gross revenue in each year of the analysis.

(16) Insurance reflects the total liability insurance premiums for the building. Management's 2005 budgeted amount grows by $3 \%$ per annum.

(17) Association Dues reflect annual assessments by the owner's association. Management's 2005 budgeted amount inflates 3\% annually.

(18) Real Estate Taxes for the first year of the analysis reflect the projected 2005 property taxes that will be paid in 2006 . The first year taxes are estimated by inflating the actual aggregate 2004 tax rate of $\$ 3.09125$ by $3 \%$ and applying the result to the 2004 assessed value of $\$ 18,332,620$. Property taxes for 2006, which are paid in 2007 , assume the property is reassessed to $70 \%$ of the sales price and are subject to the inflated 2005 tax rate of $\$ 3.18399$ inflated by $3 \%$. Thereafter, property taxes increase $3 \%$ annually.

(19) Non-Recoverable includes directly billed overtime electricity $(\$ 50,100)$, parking sales taxes $(\$ 4,358)$, and delivery expense $(\$ 1,000)$. The aggregate amount inflates $3 \%$ per annum.

(20) Tenant Improvements reflects the total cost to build out leased office areas for both new and renewing tenants. New leases on second-generation space receive a $\$ 15$ allowance, while all renewing leases are granted a $\$ 6$ allowance. The assumed amounts for the tenant improvement allowances are expressed in 2006 dollars. Tenant improvement allowances for second-generation space grow annually by the general inflation rate.

(21) Leasing Commissions are calculated as $6 \%$ of the net effective value of the lease on new leases and 5\% for all renewals. All leasing commissions are assumed to be funded $100 \%$ upon occupancy.

(22) Capital Reserves of $\$ .10$ per square foot are funded in 2006 and increase 3\% annually thereafter.

\section{$\overline{\text { REFERENCES }}$}

National Association of Real Estate Investment Trusts. (2007). Frequently Asked Questions About REITs: Answers to Fundamental Questions About REITs. Washington, D.C. 


\section{INSTRUCTORS' NOTES}

\section{REAL ESTATE CONCEPTS}

Included in the text of the case are details related to Real Estate Investment Trusts (REITs). This information is not necessarily pertinent to the calculations required to make decisions about whether to purchase the property in question (The Forum), but rather to expose students to an industry they might not otherwise be exposed to in a typical course in financial management. REITs (both public and private) are a driving force in the market for commercial real estate, and they own many of the properties that other types of businesses lease space from to conduct their operations. In other words, students stand a good chance of a REIT being their commercial landlord.

The details in the included offering memorandum closely resemble that of an actual property that sold in the Energy Corridor of the Houston office market in 2005. The name of the property and tenants have been altered, but the express permission of the selling broker to use the offering memorandum has been given. It is an actual real estate deal in a large submarket of a major US city. The math involved in the analysis of the purchase is just difficult enough to give students a feel for how complex real estate valuation can be - especially the estimation of expected future cash flows. The property has four tenants - which is a sweet spot. A single tenant property is substantially easier to analyze. A thirty-tenant property is substantially more difficult.

\section{SUGGESTED QUESTIONS FOR STUDENTS}

As students analyze the merits of this investment opportunity, here is a list of questions intended to spark discussion of this capital budgeting opportunity. Possible solutions are included.

1. Should you purchase the building?

Answer: As with all capital budgeting questions, the answer depends on the NPV of the investment opportunity. Student answers here will vary. There are MANY potential inputs and considerations when identifying the marginal cash flows associated with the office property.

Students should not rely on the analysis conducted by the selling agent. The agent's motivation is to generate as high of a sales price 
for the property as possible. He or she will make the numbers look as rosy as can be for the existing set of contracts. Students should be skeptical of all the inputs. Remember, real estate is sold via a firstprice sealed-bid auction, and the principles of the winner's curse certainly applies. The buyer should conduct the financial analysis assuming the worst case scenario. An example of this is parking revenue. Current tenants are paying for parking, but remember that this is a suburban office property in Houston, Texas. Land (and parking) are in abundance. Chances are good that as tenants renew, they will be less likely to pay top dollar for parking spaces as the building ages.

2. What is an appropriate offer price?

Answe $P$ detailed Excel analysis is available from the author via email at trazeale@shsu.edu. A conservative estimate for an appropriate purchase price is between $\$ 18-20$ million.

Note that our solution is extremely conservative. We've included none of the rooftop income or parking revenue in the analysis. We've not assumed any increase in rental rates (or expenses) over the next ten years. It may be the case that these adjustments may need to be made in order to be competitive, but technology changes (rooftop). Also, our solution provides expected future cash flows on an annual basis. More precise estimates should be calculated on a monthly basis since rent is paid twelve times a year.

3. What makes you comfortable about the purchase?

Answer: The number one thing that real estate purchasers are concerned about is the financial well-being of the tenants on the Rent Roll. Each of the firms are of quality credit, and that is comforting (although a formal credit analysis is anticipated during due diligence).

Another nice thing about the property is that it is a relatively new property. Capital expenditures in the first years of ownership (other than leasing costs) should be minimal. The roof and heating/ cooling system are in good shape - as is the garage, elevators and life safety systems. 
4. What makes you uncomfortable about the purchase?

Answer: The property is $100 \%$ leased to four tenants, but each of them do not occupy $25 \%$ of the property. AAA Oil is the 800 -pound gorilla. The financial success of the investment will be determined by whether or not they intend to renew their lease at the property. Their renewal option has sweeteners, but will they be enough to keep AAA Oil at the building - paying rent?

5. What type of change(s) in your assumptions would cause you to change your answer to question (2)?

Answer: AAA Oil is modeled as having a 75\% likelihood of renewal. If they are less likely to renew than that, then the purchase offer should be lower. Their option to renew states that they can renew at $95 \%$ of the current market rate (currently $\$ 23.00$ ). Will they really stay at that price? They currently only pay $\$ 18.61$ per square foot per year. Increasing from $\$ 18.61$ to $\$ 21.85$ is an extra $\$ 362,000$ per year in rent. That may be enough for them to leave - unless you are willing to accept a lower rental rate.

6. What aspects of this real estate case differ from other industrial problems or cases that you've worked through in the past?

Answer: Student answers to this question will vary with their previous experience. Most student experiences have likely involved production questions (quantity and price) to obtain expected future cash flows. Here they are asked to evaluation lease contracts (effectively receivables).

\section{BRIEF BIOGRAPICAL SKETCH OF AUTHOR}

Dr. Jonathan Breazeale is Associate Professor of Finance at Sam Houston State University - where he teaches Business Finance, Financial Markets and Institutions, and Security Analysis and Portfolio Management. His research interests include real estate, financial education, and working with students interested in publishing research - at both the undergraduate and graduate levels. Prior to becoming a professor, Dr. Breazeale was Vice President of Parkway Properties, Inc. (NYSE: PKY), a public real estate investment trust (REIT) invested in office properties. 